\title{
Financial Management In Improving Welfare Of Fish Farmers In Jampang Village, Bogor
}

\author{
Sri Nitta Crissiana Wirya Atmaja ${ }^{1}$, Wiwit Irawati ${ }^{2}$, Listya Sugiyarti ${ }^{3}$, Eka Kusuma Dewi ${ }^{4}$ \\ \{dosen00299@unpam.ac.id,dosen00869@unpam.ac.id, tya_tiyong@yahoo.com, \\ eka.kusuma.dewi@gmail.com\} \\ University of Pamulang (UNPAM), Tangerang, Indonesia
}

\begin{abstract}
The lack of knowledge about how to manage a business's finances made some Micro, Small and Medium Enterprises(MSMEs) players hampered in terms of developing their businesses. Limited educational background was also one of the factors that causes a lack of awareness of the importance of financial management in a business. This was the background of the writers (S1 Accounting Study Program Lecturer Team University of Pamulang) conducted one of the activities which was one of the Tri Dharma of College namely Community Service. This activity was carried out in the community of fish farmer groups in Jampang Village, Kemang District, Bogor. The potential in Jampang Village was fish farmers such as catfish, ornamental fish and other freshwater fish. Jampang Village was also a tourist village known as edutainment especially for students; about how to hatch, care and so on. This activity used lectures, tutorials, and direct discussions with fish farmers. The results of the financial management activities for fish farmer group leaders could understand that with proper financial management the output would be better for the future of the fish farmers.
\end{abstract}

Keywords: Financial Management, Revenue, Fish Farmers.

\section{Introduction}

Financial Management according[1] to Horne and Wachowicz Jr. (2012: 2) in his book entitled Fundamentals of Financial Management which has been translated into Financial Management Principles suggests that: "Financial management is related to the acquisition of assets, funding, and asset management based on several general objectives". Many problems in financial management are experienced by business actors, especially Micro, Small and Medium Enterprises (MSMEs) in Indonesia. And this is also experienced by fish farmers in Jampang village. This is inseparable from the limited formal education background for almost all fish farmers, especially in the Jampang Village, Kemang District, Bogor Regency, the majority of which are graduates of Senior High Schools. There are 17 Farmer Groups in Jampang village with 213 members of the Family. The potential of Jampang Village to develop in the future is so great, and one of the obstacles is the lack of recording or bookkeeping capabilities which leads to the absence of standardized Financial Reports as a liaison between farmers and funders. Accounting practice[2] is one solution to the problem that often occurs in Micro, Small and Medium Enterprises (MSMEs), namely financial management problems. 
Accounting is used as a standard to facilitate MSMEs in making financial reports that can be accounted for and understood by external and internal parties. Accounting practices should have been widely known or even practiced by MSMEs, but in reality there are still many who have not practiced them well[3][4]. The Community Service activity carried out by the lecturers at University of Pamulang this time has the theme of Financial Management for Fish Farmers in Jampang Village, Bogor. Residents[5] in the village have livelihoods as fish farmers and so far there is still a lack of knowledge about financial management. It is hoped that by providing additional knowledge about financial management it can be a big capital in carrying out various concrete activities so that the level of quality of life and welfare of the people can increase towards a better and more prosperous[6].

The main business of fish farmers in Jampang Village is from selling freshwater livestock, namely catfish, carp, and ornamental fish. Besides that, there is also Mina Education Tourism[7] in the form of ornamental fish farm tourism village that provides education to tourism participants especially students on how to maintain water fish bargaining begins with seeding. Based on the background of the above problems, the focus of Community Service is limited to the scope to improve the standard of living of the people in the village in participating in this activity. The activities are to provide knowledge and skills through easy financial and trick management training in preparing financial reports [8].

This Community Service activity was attended by residents of Jampang Village Kemang District, Bogor Regency as many as 60 participants. The participants were enthusiastic in participating in this activity for three days[2]. Participants who participated were mostly residents who owned small businesses with capital of around Rp. 5 million to Rp. 50 million. The goals and objectives of this Community Service activity are to provide financial management training to fish farmers, as entrepreneurial capital and be able to make financial reports to be able to absorb credit as venture capital.

\section{Methodology}

The training provided[4] to fish farmers was carried out using lectures, tutorials and discussions. The stages of implementing this service activity are the Lecture Method, where participants are given insight into the importance of financial management in starting and running a business. The first material given is the factors that cause the growth and progress of the business of fish farmers, one of which is the constraints of Human Resources (HR) and financial management knowledge and the solution by providing an introduction or introduction to accounting[6][7]. The material provided is in the form of an explanation of the importance of accounting for farmers. Most participants do not understand the accounting function, even assuming that accounting is a complicated, difficult, troublesome and timeconsuming field.

The second material concerning fisheries accounting transactions. In this session, explain how to identify transactions, record up to the preparation of financial statements. As an exercise, trainees are given simple case examples and solutions. 


\section{Result}

By conducting three day trainings in Jampang Village Bogor, it was found that the fish farmers have lower educational background so that they have a little knowledge about financial management. They have also understood that financial management can only be done by them who learned in college or university. They have no ideas how to do financial management activities. After attending three day trainings which was held by Community Service from University of Pamulang, they started to understand that doing financial management can be done by everyone even though they did not attending college or university. They also understand that to get some loans from banks they must have good bookkeeping which is accountable.

\section{Conclusion}

With the presence of accounting and financial processing knowledge given to fish farmers who initially considered something complicated and difficult and could only be understood by those who went to college, they began to understand that there are simple ways that can be applied easily but remain accountable in the financial management of the fish farmer business. With counseling on simple financial management methods, it is expected that more opportunities in business development in the future will ultimately increase the income of fish farmers.

\section{References}

[1] Bringham, Eugene.F dan Joel F. Houston. (2001). Manajemen Keuangan. Ahli bahasa Dodo Suharto dan Herman Wibowo. Edisi Kedelapan. Buku I. Jakarta : Erlangga.

[2] Bringham and Houston. (2010). Dasar-dasar Manajemen Keuangan. Buku 1. (edisi 11) Jakarta : Salemba Empat.

[3] Horne, James C. Van dan John M Wachowicz, Jr. (2012). "Prinsip - prinsip Manajemen Keuangan" (Edisi 13). Jakarta : Salemba Empat.

[4] Ikatan Akuntan Indonesia. 2004. Standar Akuntansi Keuangan. Jakarta : Salemba Empat

[5] Martono dan Agus Harjito. (2010). Manajemen Keuangan (Edisi 3) Yogyakarta : Ekonisia.

[6] Pusat Bahasa Depdiknas. (2008:1767). "Kamus Besar Bahasa Indonesia (KBBI)". Jakarta.

[7] Syahyunan. (2004). Manajemen Keuangan I. Medan: USU Press.

[8] Syamsuddin, Lukman. (2004). Manajemen Keuangan Perusahaan : Konsep Aplikasi dalam: Perencanaan, Pengawasan, dan Pengambilan Keputusan. Edisi Baru. Cetakan kedelapan. Jakarta: RajaGrafindo Persada. 